\title{
MODEL LOGIKA FUZZY SUGENO BERBASIS WEB UNTUK SELEKSI PENERIMA BEASISWA
}

\author{
Heru Supriyono ${ }^{1)}$, Achmad Kurnianto ${ }^{2)}$, Muhammad Fikri Khaidir ${ }^{3)}$, Sujalwo ${ }^{4)}$ \\ ${ }^{1)}$ Program Studi Teknik Elektro - Universitas Muhammadiyah Surakarta \\ ${ }^{2,3)}$ Program Studi Informatika - Universitas Muhammadiyah Surakarta \\ ${ }^{4)}$ Program Studi Pendidikan Teknik Informatika - Universitas Muhammadiyah Surakarta \\ ${ }^{1)}$ Heru.Supriyono@ums.ac.id
}

\begin{abstract}
One of the main problems emerging in the decision making process by human is the possibilities of bias decision caused by personal factors. This paper discusses the development of a Fuzzy Sugeno based decision support systems for selecting scholarship recipients which is implemented in a web based systems. The main objectives of the research are to result a Fuzzy Sugeno model which mimic human reasoning in the scholarship selection and to calculate recommendation value of every applicant. There are five factors used in the computation involving grade point average (GPA), parent's income, number of sibling, organization activities, and achievement. Traditional system development life cycle or waterfall method was used in the system development process. Fuzzy Sugeno model is implemented mainly using Django framework with Python programming language. The result of the research is the web based decision support systems for selecting scholarship recipient. The blackbox testing of the decision support systems showed that all functions of the systems are functioning well as expected and the validation testing result using real data showed that the validity level I equals to $92.3 \%$
\end{abstract}

Keyword: scholarship selection, fuzzy logic Sugeno, decision support systems, expert systems, web-based systems

\section{PENDAHULUAN}

Beasiswa didefinisikan sebagai "pemberian berupa bantuan keuangan yang diberikan kepada perorangan yang bertujuan untuk digunakan demi keberlangsungan pendidikan yang ditempuh" (Wikipedia, 2017). Beasiswa bisa berasal dari berbagai lembaga donor baik bersumber dari pemerintah, lembaga swadaya masyarakat maupun dari perusahaan. Pemilihan penerima beasiswa pada tingkat universitas biasanya dilakukan melalui tahapan seleksi dikarenakan jumlah pendaftar lebih banyak dibandingkan dengan kuota beasiswa yang dihasilkan.

Berdasarkan hasil observasi dilapangan, proses administrasi penentuan calon penerima beasiswa dilakukan dalam beberapa tahapan meliputi: pengisian formulir pendaftaran, pengumpulan berkas, pengecekan validitas berkas, penyeleksian pendaftar dan pengumuman hasil seleksi. Rangkaian proses administrasi ini kebanyakan dilakukan secara manual. Sistem komputer bisa digunakan dalam mengotomatisasi proses administrasi manual seperti contohnya untuk proses perekapan presensi kehadiran (Supriyono, Saputra \& Pradesya, 2016) dan menawarkan keuntungan diantaranya proses penyimpanan data bisa dilakukan dengan menghemat tempat, mempermudah pembuatan laporan, mempercepat pencarian kembali data, dan dapat dikembangkan dengan aplikasi yang lainnya.

Seleksi penerima beasiswa oleh manusia mempunyai beberapa kelemahan diantaranya manusia sangat mungkin condong kepada salah satu calon tertentu karena faktor personal atau karena kinerjanya menurun akibat lelah secara fisik maupun lelah 
secara psikologi (Badiru \& Cheung, 2002; Etikareina, 2014). Untuk meminimalisir faktor personal panitia seleksi pemilihan beasiswa, dalam penelitian yang dipublikasikan ini dikembangkanlah sistem pendukung keputusan (SPK) berbasis komputer untuk proses pemilihan calon penerima beasiswa. Ada dua tujuan utama dilakukannya penelitian ini yaitu: (1) untuk menghasilkan model cara berpikirnya manusia dalam menyeleksi calon penerima beasiswa berbasis logika kabur, dan (2) menghitung nilai rekomendasi setiap pelamar beasiswa.

\section{TUNJAUAN PUSTAKA}

Ada beberapa faktor pertimbangan yang digunakan untuk menentukan penerima beasiswa diantaranya adalah nilai akademis atau indeks prestasi kumulatif (IPK), penghasilan orang tua, jumlah tanggungan orang tua/jumlah saudara kandung, usia/masa studi (Wibowo, Amalia, Fadlun, \& Arivanty, 2009). Seleksi penentuan calon penerima beasiswa biasanya dilakukan oleh petugas atau karyawan yang ditunjuk. Permasalahan muncul apabila terdapat data pendaftar yang saling berlawanan misalnya adalah ada calon yang IPKnya sangat tinggi tapi penghasilan orang tuanya juga tinggi sementara ada yang yang pendaftar yang IPKnya tidak terlalu tinggi namun penghasilan orang tuanya rendah. Kondisi seperti ini membuat petugas atau karyawan yang ditunjuk menggunakan pertimbangan-pertimbangan dan pengalamannnya untuk mendapatkan solusi yang tepat. Oleh karena itu seleksi penerima beasiswa termasuk dalam permasalahan yang semiterstruktur. Permasalahan yang bersifat semiterstruktur ini bisa diselesaikan dengan menggunakan sistem pendukung keputusan (SPK) yaitu merupakan sebuah program komputer yang mempunyai model dan algoritma penalaran layaknya manusia sehingga mampu menghasilkan keputusan untuk masukan yang diberikan (Turban, Aronson, \& Liang, 2007).

Salah satu algoritma yang berpotensi untuk digunakan pada pengembangan SPK adalah Logika fuzzy (kabur) yaitu merupakan metode komputasi yang mengadopsi bahasa linguistik yang digunakan oleh manusia dalam berkomunikasi sehari-hari (Badiru \& Cheung, 2002). Para peneliti banyak yang tertarik untuk mengaplikasikan logika kabur pada berbagai bidang dan mendapatkan hasil yang memuaskan diantaranya adalah untuk pengendalian motor induksi (Fonseca, Afonso, Martins, \& Couto, 1999), untuk pemilihan material dalam industri logam (Daws, Al-Dawood, \& Al-Kabi, 2009), untuk pemilihan manajer (Sajfert, Atanaskovic, Pamucar, \& Nikolic, 2012) dan masih banyak lagi. Sistem pendukung keputusan bisa diimplementasikan pada beberapa platform seperti dalam aplikasi desktop untuk komputer tunggal atau dalam sistem berbasis website. Implementasi SPK dalam sistem berbasis website memberikan banyak keuntungan diantaranya adalah dapat diakses dari manapun selama ada jaringan internet (Turban, Aronson, \& Liang, 2007). Salah satu contoh publikasi yang menerapkan SPK kedalam sistem berbasis web adalah pengembangan sistem pakar/ SPK dalam sistem berbasis web untuk pemilihan rumah tinggal (Supriyono \& Sari, 2015).

\section{METODE PENELITIAN}

Dalam publikasi ini, logika kabur jenis Sugeno (Takagi-Sugeno-Kang) digunakan untuk memodelkan cara berpikirnya manusia dalam seleksi calon penerima beasiswa. Kemudian model logika kabur diimplementasikan dalam sistem berbasis web.

\subsection{Penentuan Variabel Komputasi}

Seleksi calon penerima beasiswa dilakukan berdasarkan variabel masukan. Pada penelitian yang dipublikasikan ini, variabel yang digunakan untuk pertimbangan seleksi calon penerima beasiswa ditentukan secara empiris yaitu 
dengan melakukan wawancara dengan Wakil Dekan Bidang Kemahasiswaan beberapa fakultas di Universitas Muhammadiyah Surakarta untuk mengetahui faktor-faktor yang digunakan dalam seleksi. Hasil wawancara menunjukkan bahwa ada lima faktor yang digunakan untuk seleksi calon penerima beasiswa yaitu: (1) indeks prestasi kumulatif (IPK), (2) prestasi mahasiswa, (3) pendapatan orangtua, (4) jumlah tanggungan orang tua, (5) keaktifan organisasi. Masing-masing faktor akan saling mendukung atau juga bahkan saling kontradiksi.

\subsection{Proses Komputasi}

Proses komputasi seleksi calon penerima beasiswa dengan menggunakan logika kabur Sugeno secara keseluruhan dapat dilihat pada Gambar 1.

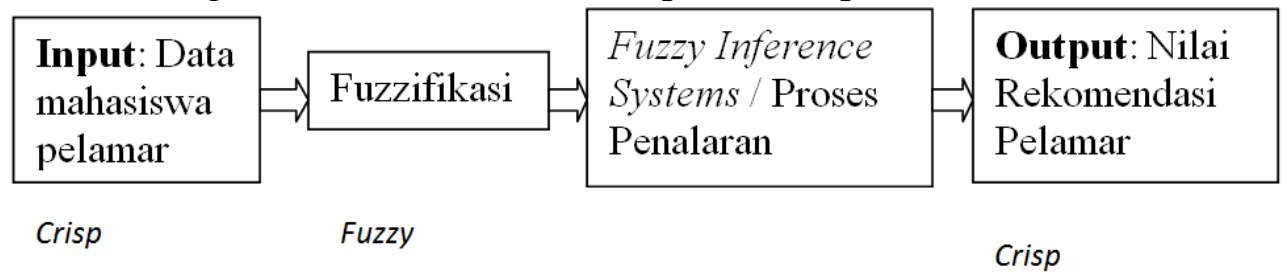

Gambar 1. Blok diagram komputasi seleksi beasiswa menggunakan logika kabur Sugeno.

Input/masukan sistem adalah berupa data lima faktor yang digunakan untuk komputasi yang diberikan oleh pelamar yang bersifat tegas/crisp yaitu berupa angka-angka. Kemudian masukan yang berupa data angka/bersifat crisp ini kemudian diubah kedalam variabel kabur/fuzzy melalui proses fuzzifikasi. Proses fuzzifikasi adalah pemetaan inputan yang berupa bilangan kedalam fungsi keanggotaan sehingga masing-masing angka/input akan mempunyai derajat keanggotaan antara [0,1]. Dalam penelitian yang dipublikasikan ini, fungsi keanggotaan yang digunakan adalah fungsi keanggotaan trapesium/bahu dan segitiga. Fungsi keanggotaan trapesium mempunyai empat buah parameter yaitu titik awal support (a), titik maksimum bawah (b), titik maksimum atas (c), dan titik akhir support (d). Apabila nila parameter a sama dengan $\mathrm{b}$ maka fungsi keanggotaan trapesium akan menjadi fungsi keanggotaan bahu miring kekiri seperti yang dapat dilihat pada Gambar 2. Fungsi keanggotaan bahu bisa juga dibuat miring kekanan apabila nilai parameter c sama dengan $d$.

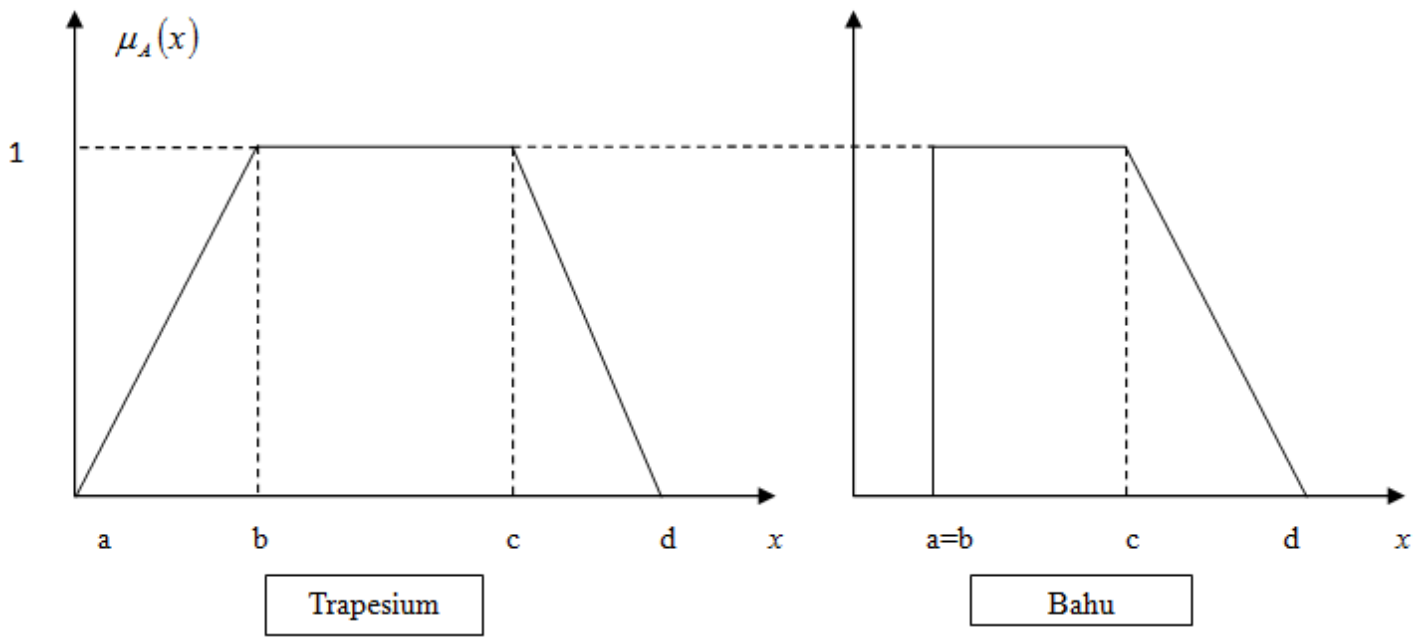

Gambar 2. Fungsi keanggotaan trapesium dan bahu 
Fungsi keanggotaan segitiga hanya mempunyai tiga buah parameter yaitu: titik awal support (a), titik maksimum/titik puncak (b), titik akhir support (c) seperti dapat dilihat pada Gambar 3.

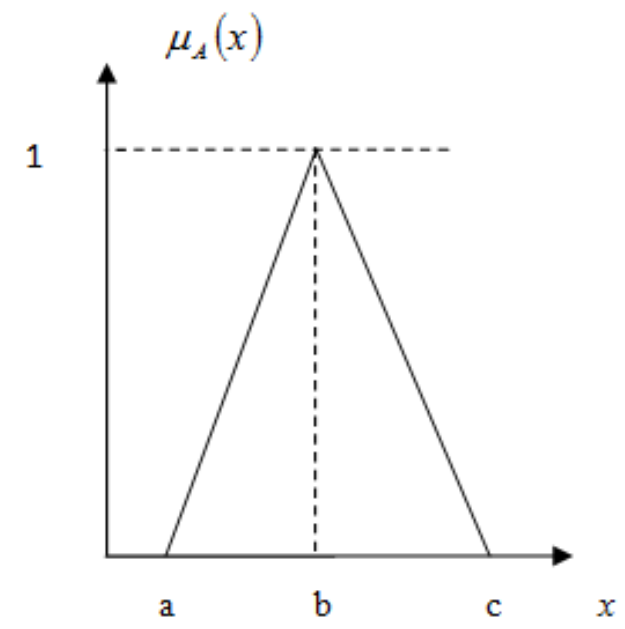

Gambar 3. Fungsi keanggotaan segitiga.

Fungsi keanggotaan ini dipilih karena fungsinya sederhana dan komputasinya sederhana dan cepat. Semesta pembicaraan yang dalam hal ini adalah data mahasiswa pelamar beasiswa untuk masing-masing variabel masukan akan dikelompokkan kedalam kelompok-kelompok kriteria bertingkat seperti rendah, sedang dan tinggi meniru seperti layaknya proses seleksi calon penerima beasiswa oleh panitia. Semua parameter/nilai dalam fungsi keanggotaan ditentukan melalui proses optimisasi dengan cara coba-coba (trial and error) berdasarkan data riil yang dipunyai untuk mendapatkan hasil yang terbaik.

a. Fungsi keanggotaan untuk indeks prestasi kumulatif (IPK)

Indeks prestasi kumulatif (IPK) mahasiswa dinyatakan dalam angka skala 4. Berdasarkan survei yang sudah dilakukan rata-rata beasiswa mensyaratkan mahasiswa pendaftar beasiswa memiliki IPK minimal 2,75. IPK rentang antara 2,75-4,0 ini kemudian dibagi menjadi 3 kelompok yaitu Rendah, Sedang dan Tinggi sebagai berikut:

- Rendah: IPK mahasiswa termasuk kelompok rendah apabila IPK berada dibawah 3 sehingga digunakanlah fungsi ekanggotaan bahu dengan nilai parameter $(2,75 ; 2,75 ; 3 ; 3,25)$

- Sedang: IPK mahasiswa termasuk kelompok sedang apabila diantara 3 dan 3,5 maka diwujudkan dengan fungi keanggotaan segitiga dengan parameter $(3 ; 3,3$; $3,5)$

- Tinggi: IPK mahasiswa termasuk kelompok tinggi apabila IPK diatas 3,5 yang kemudian diwujudkan dalam fungsi keanggotaan bahu dengan nilai parameter $(3,4 ; 3,5 ; 4 ; 4)$

Fungsi keanggotaan untuk variabel masukan IPK dapat dilihat pada Gambar 4. 


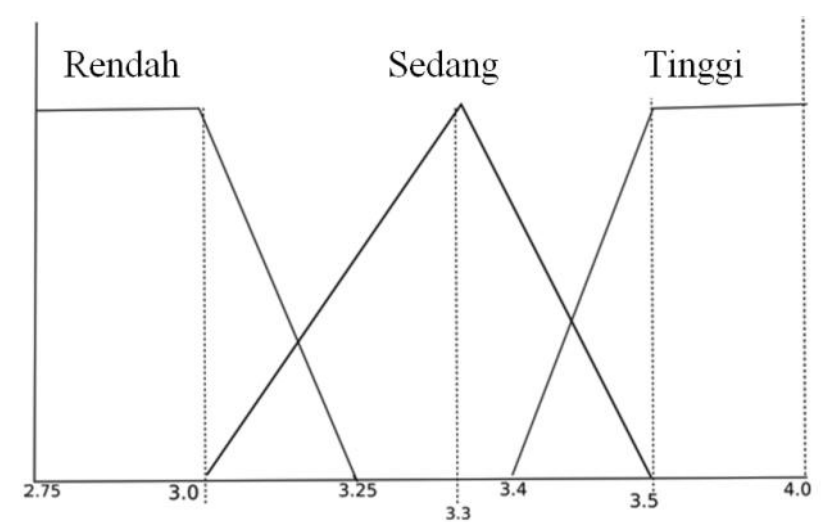

Gambar 4. Fungsi keanggotaan untuk IPK

\section{b. Fungsi keanggotaan untuk keaktifan organisasi (org)}

Aktifitas atau keaftifan mahasiswa dalam berorganisasi secara umum dapat digolongkan dalam tiga kelompok yaitu rendah, sedang dan tinggi. Variabel ini tidak berwujud angka namun berwujud tingkatan dimana mahasiswa aktf yaitu tingkat jurusan, tingkat fakultas dan tingkat universitas. Untuk mengkomputasinya maka tingkat keaktifan ini kemudian dikonversi kedalam numerik atau angka skala 8 yaitu nilai 0 apabila mahasiswa pasif dan angka 8 apabila mahasiswa menjadi pengurus organisasi tingkat universitas sehingga didapatkan nilai-nilai sebagai berikut:

- Rendah: jika mahasiswa hanya menjadi anggota sehingga dinyatakan dalam fungsi keanggotaan bahu dengan nilai-nilai parameter $(0 ; 0 ; 1 ; 2,5)$.

- Sedang: jika mahasiswa aktif menjadi pengurus himpunan mahasiswa jurusan sampai dengan pengurus himpunan mahasiswa fakultas sehingga dinyatakan dalam fungsi keanggotaan segitiga dengan nilai-nilai parameter $(2 ; 2,75 ; 3,5)$.

- Tinggi: jika mahasiswa aktif menjadi pengurus organisasi tingkat universitas sehingga dinyatakan dalam fungsi keanggotaan bahu dengan nilai-nilai parameter $(3 ; 5 ; 8 ; 8)$.

Fungsi keanggotaan untuk variabel masukan keaktifan organisasi dapat dilihat pada Gambar 5.

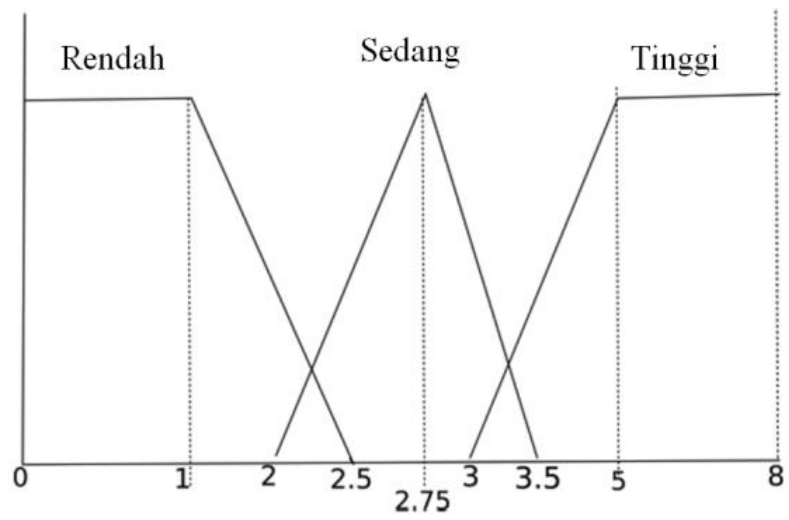

Gambar 5. Fungsi keanggotaan untuk keaktifan organisasi (org)

\section{c. Fungsi keanggotaan untuk pendapatan orang tua (pot)}

Pendapatan orang tua (pot) merupakan data total penghasilan orangtua dalam satu bulan. Data ini berupa angka dalam satuan rupiah. Dalam proses seleksi beasiswa, penghasilan orang tua dikelompokkan menjadi tiga golongan sebagai berikut: 
- Rendah: jika penghasilan orangtua kurang dari satu juta rupiah namun diatas lima ratus ribu rupiah sehingga bisa dinyatakan dalam fungsi keanggotaan bahu dengan nilai-nilai parameter dalam ratusan ribu rupiah $(500 ; 500 ; 1000 ; 2000)$.

- Sedang: jika penghasilan orangtua antara satu juta lima ratus ribu rupiah sampai dengan tiga juta lima ratus ribu rupiah yang kemudian dinyatakan dalam fungsi keanggotaan segitiga dengan nilai-nilai parameter $(1500 ; 2500 ; 3500)$.

- Tinggi: apabila penghasilan orangtua diatas lima juta rupiah yang kemudian dinyatakan dalam fungsi keanggotaan bahu dengan nilai-nilai parameter (3000; 5000; 10000).

Fungsi keanggotaan untuk penghasilan orang tua dapat dilihat pada Gambar 6 .

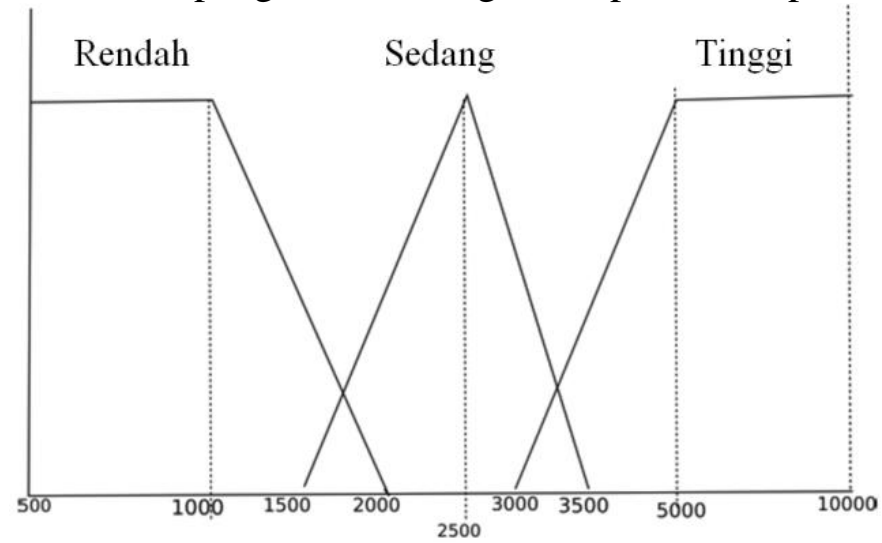

Gambar 6. Fungsi keanggotaan untuk penghasilan orang tua (pot) dalam ratusan ribu rupiah

\section{d. Fungsi keanggotaan untuk jumlah tanggungan orang tua (tan)}

Jumlah tanggungan dalam konteks seleksi beasiswa berdasarkan hasil survei adalah jumlah orang yang tinggal serumah/dalam kartu keluarga yang menjadi tanggungan kepala keluarga meliputi anak kandung dan saudara lainnya seperti kakek dan nenek. Jumlah tanggungan dikelompokkan menjadi tiga (seperti yang dapat dilihat pada Gambar 7) yaitu:

- Rendah: jika jumlah tanggungan kurang dari dua orang sehingga bisa dinyatakan dalam fungsi keanggotaan bahu dengan nilai-nilai parameter $(1 ; 1$; $2 ; 3)$

- Sedang: jika jumlah tanggungan antara dua sampai lima. Namun, dalam proses komputasi percobaan menunjukkan bahwa hasil terbaik didapatkan apabila fungsi keanggotaan yang digunakan adalah segitiga dengan nilai-nilai parameter $(2,5 ; 3,5 ; 4,5)$.

- Tinggi: jika jumlah tanggungan lebih dari lima orang yang dapat dinyatakan dengan fungsi keanggotaan bahu dengan nilai-nilai parameter $(4 ; 5 ; 10 ; 10)$.

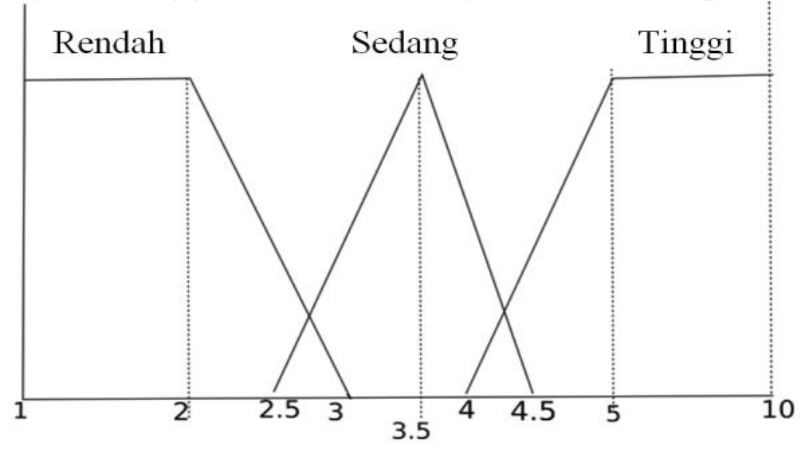

Gambar 7. Fungsi keanggotaan untuk jumlah tanggungan (tan) 


\section{e. Fungsi keanggotaan untuk prestasi mahasiswa (pre)}

Prestasi mahasiswa merupakan data deskripsi capaian yang bukan berupa angka numerik sehingga untuk bisa dikomputasi harus dikonversi kedalam angka skala 8 (dapat dilihat pada Gambar 8). Prestasi mahasiswa dikelompokkan menjadi tiga sebagai berikut:

- Rendah: jika prestasi mahasiswa pada tingkat universitas yang dinyatakan dalam fungsi keanggotaan bahu dengan parameter $(0 ; 0 ; 1 ; 2,5)$.

- Sedang: jika prestasi mahasiswa pada tingkat regional/kopertis yang dinyatakan dalm fungsi keanggotaan segitiga dengan parameter $(2 ; 2,75 ; 3,5)$.

- Tinggi: jika prestasi mahasiswa pada tingkat nasional/internasional yang dinyatakan dengan fungsi bahu dengan parameter $(3 ; 5 ; 8 ; 8)$.

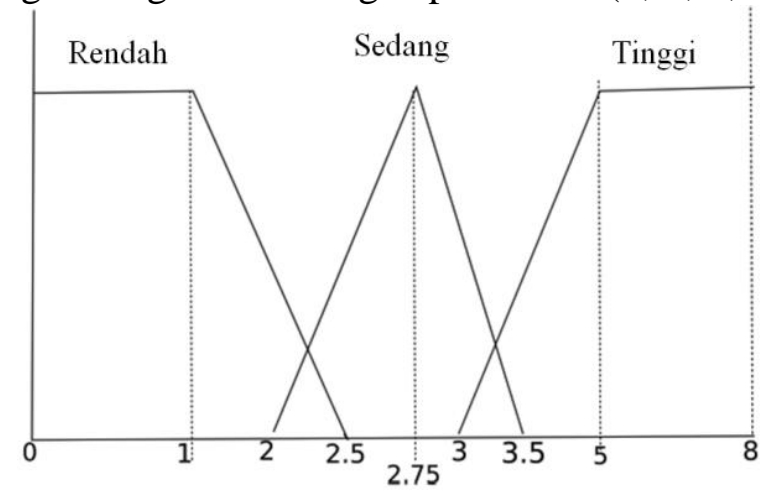

Gambar 8. Fungsi keanggotaan untuk prestasi (pre)

Lima buah variabel masukan ini kemudian diolah menggunakan sistem inferensi fuzzy yang proses bekerjanya adalah meniru seperti layaknya manusia berpikir. Sistem inferensi fuzzy Sugeno dibangun dari aturan-aturan fuzzy dengan menggunakan bentuk IF-THEN yang mempunyai bentuk umum seperti yang dapat dilihat pada persamaan 1 .

$$
\text { IF } x \text { is A AND } y \text { is B THEN } z=f(x, y)
$$

dengan $x$ adalah variabel masukan yang pertama, A adalah salah satu fungsi keanggotaan pada variabel $x, y$ adalah variabel masukan yang kedua, B adalah salah satu fungsi keanggotaan pada variabel $y$, dan $z$ adalah keluaran yang dihasilkan untuk masing-masing aturan fuzzy. Apabila jumlah input yang digunakan pada pengembangan sistem pakar adalah lima maka akan ada lima variabel pada bagian IF. Pada publikasi ini logika kabur Sugeno yang digunakan adalah orde ke-0 sehingga keluaran $z$ merupakan bilangan konstan. Total ada 243 aturan yang digunakan untuk membuat sistem pakar ini. Setiap aturan akan menghasilkan keluaran. Data-data setiap mahasiswa yang dimasukkan akan dikonversi kedalam fungsi keanggotaan dan akan diolah dengan menggunakan fungsi keanggotaan yang ada untuk menghasilkan keluaran. Untuk mendapatkan nilai akhir, pada publikasi ini digunakan metode weighted average dari keluaran masing-masing aturan dengan menggunakan persamaan 2 .

$$
z^{*}=\frac{\sum_{i=1}^{N} w_{i} z_{i}}{\sum_{i=1}^{N} w_{i}}
$$


Hasil akhir komputasi $\left(z^{*}\right)$ merupakan nilai rekomendasi setiap pelamar beasiswa. Semakin tinggi nilai rekomendasi seorang pelamar berarti semakin besar peluangnya untuk mendapatkan beasiswa.

\subsection{Perancangan Sistem}

Sistem pendukung keputusan (SPK) seleksi calon penerima beasiswa ini diimplementasikan dalam sebuah sistem berbasis web menggunakan metode system development life cycle (SDLC) yang juga dikenal dengan metode waterfall (Pressman, 2001). Proses pertama pada waterfall adalah analisis kebutuhan. Kebutuhan utama dalam sistem ini adalah seorang pengguna akan bisa "berinteraksi" dengan sistem melalui user interface (tampilan sistem). Masingmasing pengguna/pelamar beasiswa dapat memasukkan datanya melalui antarmuka yang data ini kemudian akan diolah oleh sistem inference engine (mesin inferensi) fuzzy Sugeno yang berbasis aturan-aturan fuzzy yang sudah disusun. Susunan aturan-aturan fuzzy akan membentuk knowledge base (basis aturan). Arsitektur SPK secara keseluruhan dapat dilihat pada Gambar 9.

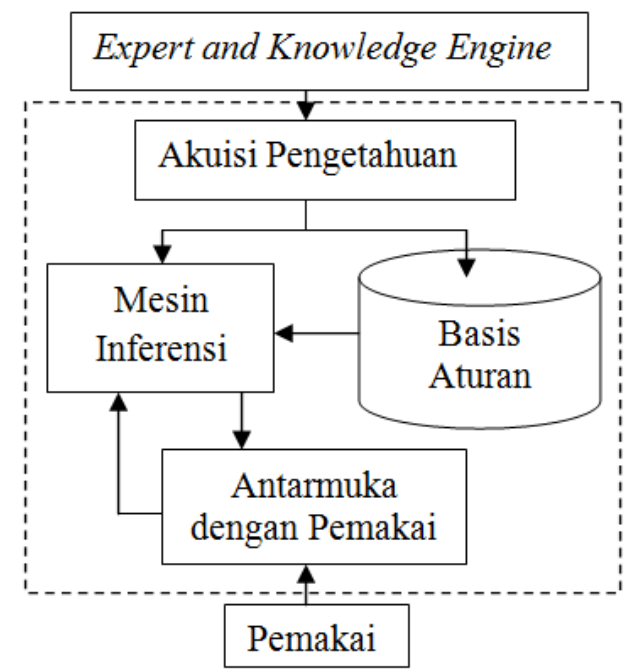

Gambar 9. Arsitektur SPK yang diimplementasikan.

Selain dapat memasukkan data, antarmuka sistem juga memungkinkan pengguna untuk mendapatkan keluaran hasil pengolahan sistem seperti mencetak validasi ataupun melihat nilai rekomendasi atau mendapatkan hasil akhir. Proses komputasi implementasi sitem pendukung keputusan dalam lingkungan berbasis web dapat dilihat pada diagram alir pada Gambar 10. 


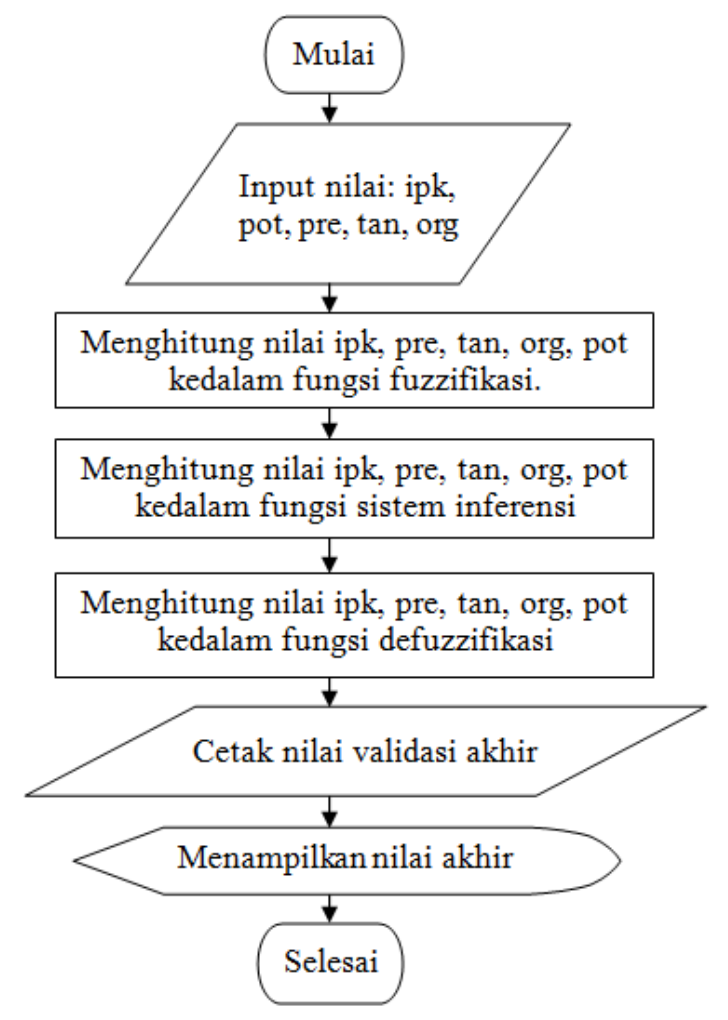

Gambar 10. Diagram alir sistem.

Pengguna SPK seleksi penerimaan beasiswa ini dua aktor yaitu anggota (member) yang mempunyai hak akses sebagai pengguna biasa dan administrator (admin) yang mempunyai hak akses sebagai pengelola. Aktifitas yang bisa dilakukan oleh masing-masing aktor dirangkum dalam sebuah usecase diagram yang dapat dilihat pada Gambar 11. 


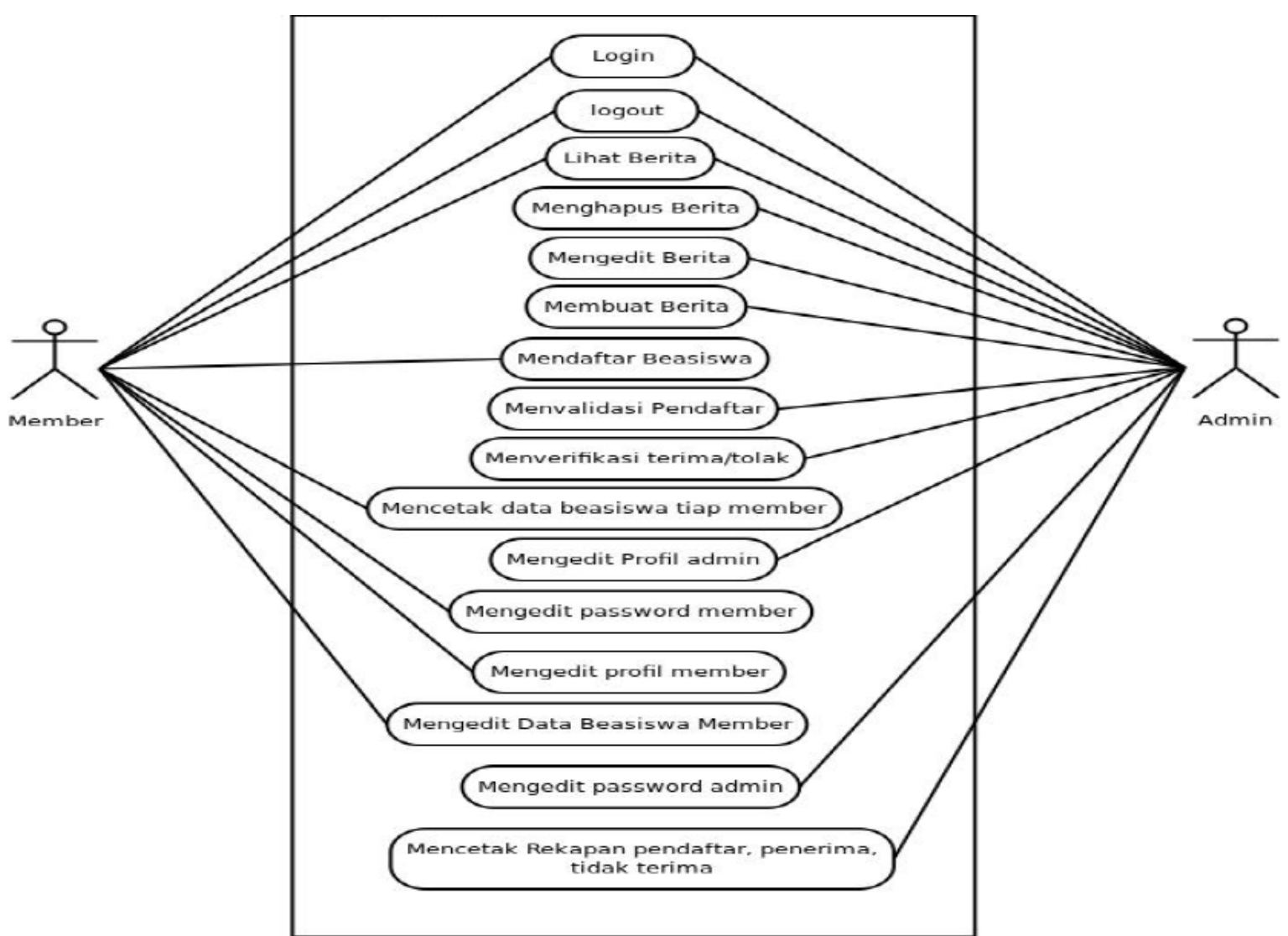

Gambar 11. Usecase diagram untuk SPK yang dibuat

\section{HASIL DAN PEMBAHASAN}

\subsection{Hasil}

Hasil dari penelitian yang dipublikasikan ini berupa SPK seleksi penerimaan beasiswa berbasis web yang beberapa tampilannya dapat dilihat seperti pada Gambar 12-15.

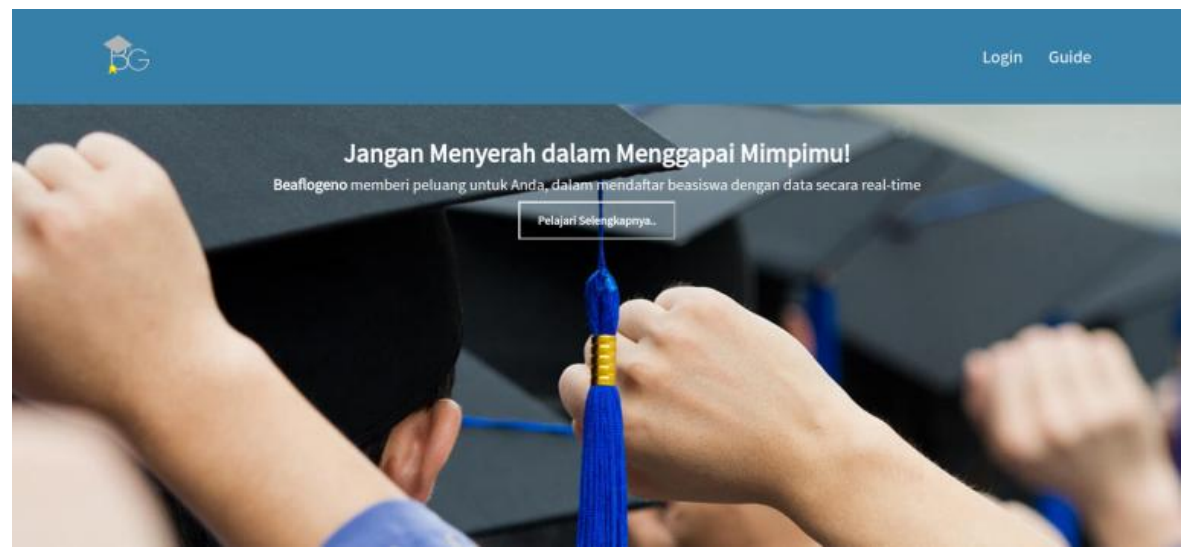

Gambar 12. Tampilan halaman awal SPK seleksi calon penerima beasiswa. 


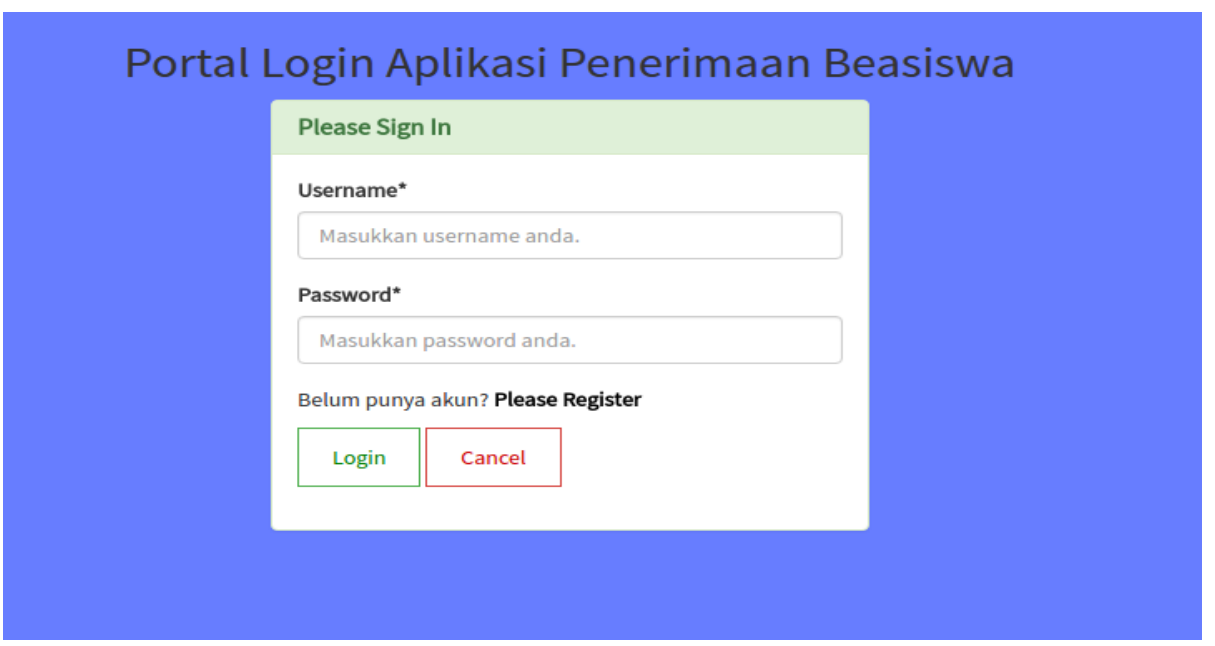

Gambar 13. Tampilan halaman masuk/login.

Data Beasiswa

Peringatan!! Print laman ini untuk bukti tanda pendaftaran online

\begin{tabular}{ll} 
Identitas & Keterangan \\
Nama & Muhammad Muchtar Arifin \\
Fakultas & Teknik \\
Program Studi & Elektro \\
NIM & D400140077 \\
Alamat & Tegal Mulyo Rt.004/Rw.002, Kecamatan Keluang Kabupaten Musi Banyuasin \\
Tanggal Lahir & July 11,1996 \\
Semester & 5 \\
IPK & 3.04 \\
Tanggungan Orang Tua & 3.0 \\
Pendapatan Orang Tua/Bulan & Rp 4500000.0 \\
\hline BPrint CE Edit &
\end{tabular}

Gambar 14. Tampilan halaman data pelamar beasiswa.

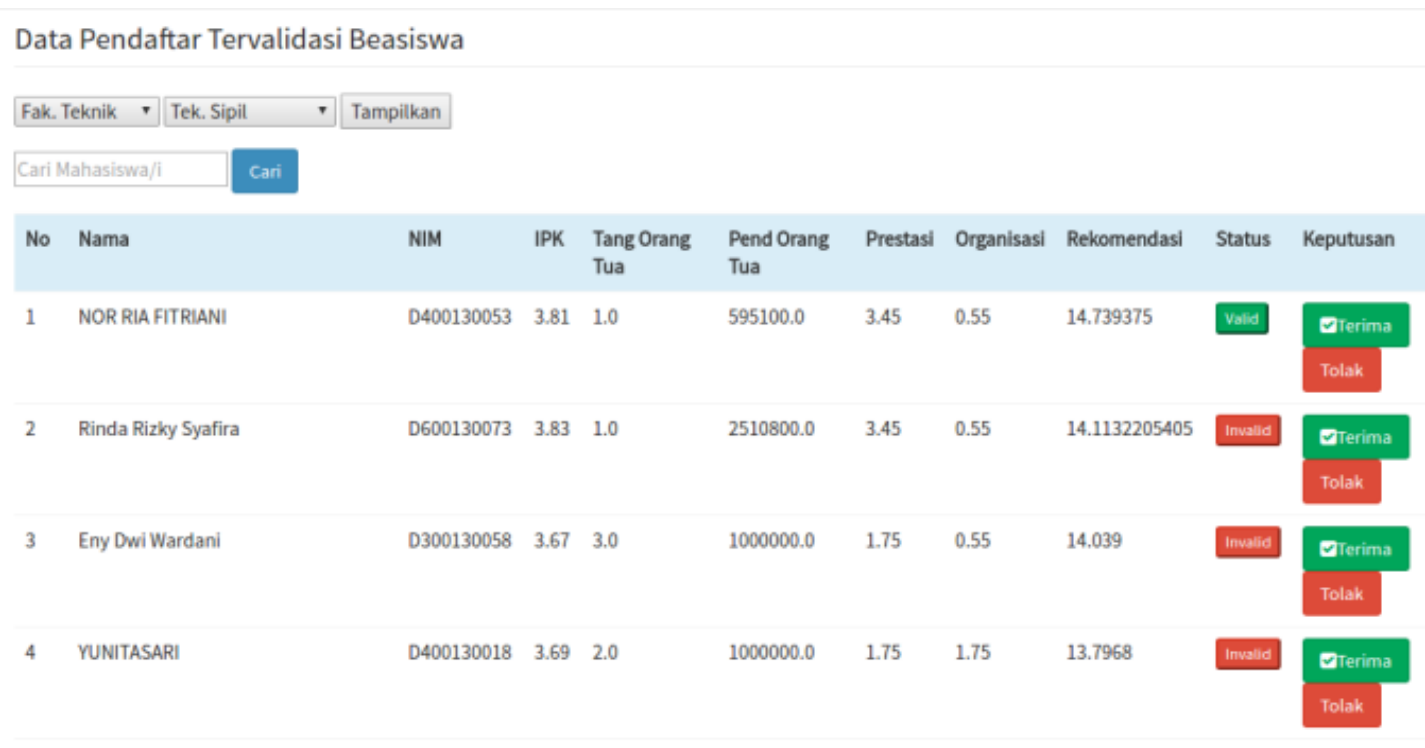

Gambar 15. Tampilan halaman rekap pelamar dan nilai rekomendasinya 


\subsection{Pembahasan}

Dalam pembuatan suatu aplikasi perangkat lunak harus dilakukan sebuah pengujian yang bersifat validasi apakah perangkat lunak yang dibuat sudah sesuai dengan kebutuhan (Pressman, 2001). Model pengujian yang digunakan dalam proses validasi adalah pengujian blackbox yang merupakan rangkaian pengujian berurutan pada fungsi atau subsistem dengan memberikan sebuah stimulus untuk mengetahui tingkah laku fungsi tersebut. Hasil pengujian blackbox dinyatakan dalam bahasa yang menggambarkan kesesuaian terhadap spesifikasi. Hasil pengujian blackbox yang sudah dilakukan untuk SPK yang dibuat pada Tabel 1 menunjukkan bahwa aplikasi yang dibuat sudah sesuai dengan yang dibutuhkan.

Tabel 1. Hasil pengujian blackbox

\begin{tabular}{|l|l|l|}
\hline No. & Fungsi yang Diuji & Hasil \\
\hline 1 & Menu dashboad & sesuai \\
\hline 2 & Menu lihat pendaftar & sesuai \\
\hline 3 & Menu validasi pendaftar & sesuai \\
\hline 4 & Menu validasi diterima & sesuai \\
\hline 5 & Menu validasi tidak diterima & sesuai \\
\hline 6 & Menu hapus semua & sesuai \\
\hline 7 & Manajemen pengelolaan pencetakan & sesuai \\
\hline 8 & Menu FAQ & sesuai \\
\hline 9 & Menu edit profil & Sesuai \\
\hline 10 & Menu edit password & sesuai \\
\hline 11 & Menu log out & Sesuai \\
\hline 12 & Menu log in & sesuai \\
\hline 13 & Menu manajemen dan lihat berita & sesuai \\
\hline 14 & Menu timeline & sesuai \\
\hline
\end{tabular}

Bagian terakhir dari pengujian pengembangan aplikasi perangkat lunak adalah pengujian tingkat penerimaan pengguna atau acceptance test (Sommerville, 2011). Pada prinsipnya tes penerimaan adalah untuk mengetahui apakah fasilitas/fitur/menu secara keseluruhan sudah sesuai dengan kebutuhan. Dalam pengujian tingkat penerimaan pengguna, pengguna akan diminta untuk mencoba sistem secara keseluruhan dengan menggunakan data riil pada sistem setelah itu diminta menjawab pertanyaan atau menanggapi pernyataan pada kuesioner yang sudah dipersiapkan. Pada pengujian dalam kuesioner terdapat lima peryataan yaitu: (1) tampilan website menarik, (2) website mudah dioperasikan, (3) warna menarik, (4) desain susunan tampilan menarik, dan (5) konten sudah memenuhi kebutuhan. Pada pengujian ini, untuk setiap pernyataan, responden umum diminta untuk memilih lima jenis tanggapan yang sudah disediakan dengan masing-masing tanggapan memiliki bobot yang berbeda-beda sesuai dengan skala likert yaitu meliputi: sangat setuju/SS (bobot 5), setuju/S (bobot 4), netral/N (bobot 3), tidak setuju/TS (bobot 2), dan sangat tidak setuju/STS (bobot 1). Pengujian tingkat penerimaan ini melibatkan sepuluh orang mahasiswa sebagai responden. Hasil kuesioner menunjukkan rata-rata $78 \%$ responden menyatakan setuju/S untuk kelima pernyataan yang diajukan dalam kuesioner.

Rangkaian berikutnya dalam pengujian tingkat penerimaan adalah pengujian tingkat validitas hasil rekomendasi SPK yang dibuat. Proses pengujian dilakukan dengan cara membandingkan hasil rekomendasi keluaran SPK dengan 
penerima beasiswa yang sesungguhnya (hasil dari proses seleksi penerima beasiswa yang sesungguhnya) seperti yang ditunjukkan pada diagram blok Gambar 16.

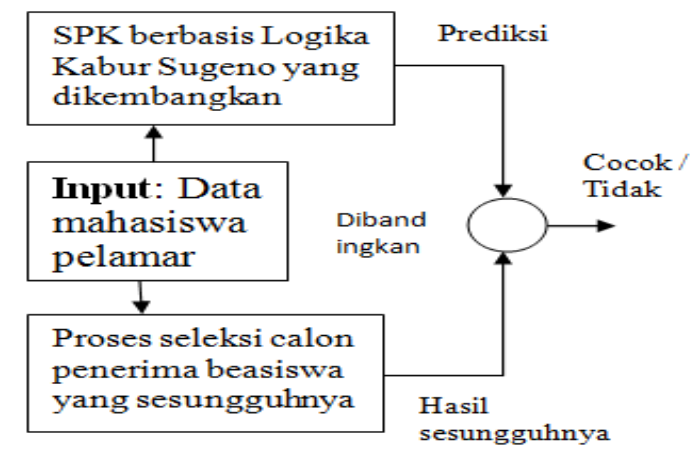

Gambar 16. Alur proses pengujian tingkat validitas

Tes tingkat validitas ini dilakukan dengan menggunakan data riil yaitu seleksi Beasiswa Toyota untuk mahasiswa Fakultas Teknik Universitas Muhammadiyah Surakarta. Setiap tahunnya kuota Beasiswa Toyota adalah sebesar 13 mahasiswa sedangkan yang mendaftar lebih dari seratus orang mahasiswa. Hasil perbandingan antara prediksi/rekomendasi dapat dilihat pada Tabel 2.

Dari hasil pengujian tingkat validitas yang ditampilkan pada Tabel 2 dapat dilihat bahwa ada 12 prediksi yang cocok dengan hasil yang sesungguhnya dari total 13 total penerima beasiswa sehingga nilai tingkat validitasnya dapat dihitung sebagai berikut:

$$
S=\frac{\text { Cocok }}{\text { TotalData }} \times 100 \%=\frac{12}{13} \times 100 \%=92,3 \%
$$

Jika dibandingkan dengan hasil penelitian yang lalu yang juga dilakukan oleh tim peneliti yaitu pengembangan SPK dengan berbasis logika fuzzy Mamdani dalam (Supriyono, Khaidir, Kurnianto, \& Sujalwo, 2017) dapat dilihat bahwa tingkat validitas hasil yang didapat sama yaitu dalam kisaran diatas $90 \%$.

Tabel 2. Pengujian tingkat validitas keluaran SPK

\begin{tabular}{|l|l|l|l|}
\hline No. & $\begin{array}{c}\text { Nama Penerima Beasiswa } \\
\text { Sesungguhnya }\end{array}$ & \multicolumn{1}{|c|}{$\begin{array}{c}\text { Prediksi Dari SPK yang } \\
\text { dikembangkan }\end{array}$} & Keterangan \\
\hline 1 & Rinda Rizky Syafira & Rinda Rizky Syafira & Cocok \\
\hline 2 & Fiki Chandra Setiyawan & Fiki Chandra Setiyawan & Cocok \\
\hline 3 & Nor Ria Fitriani & Nor Ria Fitriani & Cocok \\
\hline 4 & Yunitasari & Yunitasari & Cocok \\
\hline 5 & Bella Wahyu Ardiyanti & Bella Wahyu Ardiyanti & Cocok \\
\hline 6 & Masrifatul Nurul Ulfa & Masrifatul Nurul Ulfa & Cocok \\
\hline 7 & Arwansah Agung Rahayu & Arwansah Agung Rahayu & Cocok \\
\hline 8 & Fachrudin Syahid & Fachrudin Syahid & Cocok \\
\hline 9 & Eny Dwi Wardani & Eny Dwi Wardani & Cocok \\
\hline 10 & Redhita Ria Permatasari & Redhita Ria Permatasari & Cocok \\
\hline 11 & Ating Ratna Johar & Ating Ratna Johar & Cocok \\
\hline 12 & Aditya Hendra Nugroho & Aditya Hendra Nugroho & Cocok \\
\hline 13 & Muhammad Lutfi Saqqo & Kholid Adi Nur Ichsan & Tidak Cocok \\
\hline
\end{tabular}

\section{KESIMPULAN DAN SARAN}

\subsection{Kesimpulan}

Dari hasil proses perancangan dan pengujian dapat diambil kesimpulan:

1. SPK berbasis logika kabur Sugeno sudah berhasil dibuat untuk sistem seleksi beasiswa dalam lingkungan berbasis website, 
2. Hasil pengujian blackbox menunjukkan semua fitur/fungsi sistem berjalan sesuai dengan yang dibutuhkan,

3. Hasil pengujian tingkat penerimaan menunjukkan bahwa $78 \%$ responden menyatakan setuju sistem sudah sesuai dengan yang dibutuhkan dan juga hasil pengujian dengan menggunakan data yang nyata menunjukkan bahwa hasil keluaran SPK mempunyai tingkat validitas sebesar 92,3\% ketika dibandingkan dengan hasil proses seleksi penerima besiswa yang sesungguhnya.

\subsection{Saran}

Penelitian ini bisa dilanjutkan dengan pengembangan interface berbasis aplikasi Android untuk mengikuti tren perkembangan teknologi pada masyarakat.

\section{PERSANTUNAN}

Tim penulis mengucapkan terima kasih pada Lembaga Penelitian dan Pengabdian pada Masyarakat (LPPM) Universitas Muhammadiyah Surakarta yang sudah memberikan dana penelitian melalui skim Penelitian Reguler Kompetitif (Perekom).

\section{DAFTAR PUSTAKA}

Badiru, A., \& Cheung, J. Y. (2002). Fuzzy Engineering Expert Systems With Neural Network. New York: John Wiley and Sons.

Daws, K. M., Al-Dawood, Z. I., \& Al-Kabi, S. H. (2009). Fuzzy Logic Approach for Metal Casting Selection Process. Jordan Journal of Mechanical Engineering, Vol. 3, No. 3, 162-167.

Etikariena, A. (2014). Perbedaan Kelelahan Kerja Berdasarkan Makna Kerja Pada Karyawan. Psikogenesis, Vol. 2, No. 2, 169-179.

Fonseca, J., Afonso, L.J., Martins, J. S., \& Couto, C. (1999). Fuzzy Logic Speed Control of an Induction Motor. Microprocessors and Microsystems, Vol. 22, No. 1999, 523-534.

Pressman, R. S. (2001). Software Engineering A Practitioner's Approach, $5^{\text {th }}$ ed. Boston: McGraw-Hill.

Sajfert, Z., Atanaskovic, P., Pamucar, D., \& Nikolic, M. (2012). Application of Fuzzy Logic Into Process of Decision Making Regarding Selection of Managers. African Journal of Business Management, Vol 6, No. 9, 3221-3233.

Sommerville, I. (2011). Software Engineering, Ninth Edition. Boston: Addison-Wesley.

Supriyono, H., Saputro, N. A. \& Pradessya, R. A. (2016). Rancang Bangun Sistem Informasi Manajemen Presensi Berbasis SMS Gateway (Studi Kasus : SMP Muhammadiyah 1 Kartasura). Prosiding The 3rdUniversty Research Coloquium 2016. 13 Februari 2016. ISSN 2407-9189, 1-15

Supriyono, H., Khaidir, M.F., Kurnianto, A., \& Sujalwo. (2017). Implementasi Logika Kabur Untuik Seleksi Calon Penerima Beasiswa Dalam Sistem Berbasis Web. Prosiding The $5^{\text {th }}$ Urecol 2017, Yogyakarta, 18 Februari 2017, 1171-1178.

Supriyono, H. \& Sari, C.P. (2015). Pemilihan Rumah Tinggal Menggunakan Metode Weighted Product. Khazanah Informatika, Vol. I No. 1, 23-28.

Turban, E., Aronson, J. E., \& Liang, J. P. (2007). Decision Support Systems and Intelligent Systems $7^{\text {th }}$ Edition. New Delhi: Prentice Hall.

Wibowo, H., Amalia, R., Fadlun, A., \& Arivanty, K. (2009). Sistem Pendukung Keputusan Untuk Menentukan Penerima Beasiswa Bank BRI Menggunakan FMADM (Studi Kasus: Mahasiswa Fakultas Teknologi Industri Universitas Islam Indonesia). Prosiding Seminar Nasional Aplikasi Teknologi Informasi (SNATI) 2009, Yogyakarta, 20 Juni 2009, B-62-B-67.

Wikipedia, Beasiswa, https://id.wikipedia.org/wiki/Beasiswa (diakses 19 September 2017) 